\title{
Performance Test of GTA 5 Game with MSI Afterburner
}

\author{
Fatma Nur Canoğlu ${ }^{*}$, Mahmut Melikșah Doğan² ${ }^{2}$, Mehmet Özel $^{3}$, Oğuzhan Șengüler ${ }^{4}$, Fatih Bașçiftçi ${ }^{5}$ \\ ${ }^{1 *}$ Selçuk University, Faculty of Technology, Departmant of Information Technology Engineering, Konya, Turkey, (ORCID: 0000-0003-1357-0419), \\ fatmanurcanoglu@gmail.com \\ ${ }^{2}$ Selçuk University, Faculty of Technology, Departmant of Information Technology Engineering, Konya, Turkey, (ORCID: 0000-0003-2623-0130), \\ meliksahdogan02@gmail.com \\ ${ }^{3}$ Selçuk University, Faculty of Technology, Departmant of Information Technology Engineering, Konya, Turkey, (ORCID: 0000-0002-6924-7904), \\ mehmet.ozel@gmail.com \\ ${ }^{4}$ Selçuk University, Faculty of Technology, Departmant of Information Technology Engineering, Konya, Turkey, (ORCID: 0000-0002-0979-1166), \\ oguzhansenguler@gmail.com \\ ${ }^{5}$ Selçuk University, Faculty of Technology, Departmant of Information Technology Engineering, Konya, Turkey, (ORCID: 0000-0003-1679-7416), \\ basciftci@ selcuk.edu.tr
}

(1st International Conference on Applied Engineering and Natural Sciences ICAENS 2021, November 1-3, 2021)

(DOI: 10.31590 /ejosat.992188)

ATIF/REFERENCE: Canoğlu F.N., Doğan M.M., Özel M., Şengüller O., Başçiftçi F. (2021). Performance Test of GTA 5 Game with MSI Afterburner. European Journal of Science and Technology, (28), 172-177.

\begin{abstract}
In the technology universe, change has emerged with development. The reason for this change can be shown as applications and software that force technology, but it can also be caused by other games that offer more dynamic and realistic environments. The game industry has a great place in the technology world. They come together from various regions of the world and play games together. The innovations in the developing game industry cause various innovations in the computer hardware world. High bandwidth internet, main card, and processors with high data paths, self-controlling, and high surveillance cards are examples. While the latest models, new models in the technology market, new versions in the technology market, while transferring to new systems in the state-of-the-art market. With its different performance and prices, it also includes optimization differences. As in any other benchmarking comparison that is faced with benchmarking in terms of the differences it lives in. With the application opening, the process is started by selecting the game word to be the visual settings level. They are produced by testing on different systems, they are the average FPS values obtained during the test. The benchmarks aim to ensure that the systems make the right decision by indicating the good and the bad sides of each other. Although the user chooses according to these comparisons, they test them on their systems. A vital value for the game world, the "FPS" (Frames Per Second) value represents the biggest cutthroat for writing. In this test, the "FPS" comparison is made by trying different technologies on the same game. The test results are ranked by determining the scores. The characteristic of the scores is that they are based on the test average FPS value.
\end{abstract}

Keywords: Game performance test, computer game, FPS test.

\section{MSI Afterburner ile GTA 5 Oyununun Performans Testi}

$\ddot{O} \mathbf{z}$

Teknoloji evreninde değişim, gelişim ile birlikte ortaya çıkmıştır. Bu değişimin sebebi, teknolojiyi zorlayan uygulamalar ve yazılımlar olarak gösterilebilir ancak diğer taraftan da kullanıcılara daha dinamik ve gerçekçi ortamlar sunan oyunlardan da kaynaklanabilmektedir. Teknoloji dünyasında oyun sektörünün yeri çok büyüktür. Dünya’nın çeşitli bölgelerinden oyuncular, aynı ortamda bir araya gelerek beraber oyun oynamaktadırlar. Gelişen oyun sektöründeki yenilikler bilgisayar donanım dünyasında da çeşitli yeniliklere sebep olmaktadır. Bant genişliği yüksek internet, yüksek veri yollarına sahip ana kart ve işlemciler, kendini kontrol edebilen ve yüksek performanslı ekran kartları bunlara örnektir. Gelişen sistemler zaman içerisinde yerlerini yeni sistemlere bırakırken, son nesil olarak adlandırılan en yeni modeller, teknoloji pazarında büyük yer bulmaktadır. Her birinin farklı performans ve fiyatları olmasıyla beraber aynı zamanda da optimizasyon farklarını da içinde barındırmaktadır. İçinde barındırdığı farklar bakımından yüzlerce hatta binlerce kıyaslama ile karşı karşıya kalan kullanıcılar, soluğu benchmark kıyaslamasında almaktadır. Uygulama açılımı ile birlikte oyun 
içerisinde görsel ayarlar maksimum düzey olacak şekilde seçilerek değerlendirme işlemine başlanmış olur. Farklı sistemler üzerinde test edilerek ortaya çıkan skorlar, test süresince elde edilen ortalama FPS (Frame Per Second) değerlerinin kendisidir. Kıyaslamalar sistemlerin birbirlerine göre iyi ve kötü yanlarını belirterek doğru karar vermelerini sağlamayı amaçlamaktadır. Kullanıcılar her ne kadar bu kıyaslamalara göre tercih yapsalar da aldıkları ürünün kendi sistemlerinde çalışmasını kendilerince test etmektedirler. Oyun dünyası için hayati bir değer oran "FPS” (Frame Per Second) değeri, kullanıcılar için en büyük kıyası ifade etmektedir. Bu çalışmamızda, aynı oyun üzerinde farklı teknolojik ürünleri deneyerek "FPS” kıyaslaması yapılmaktadır. Test sonuçları skorlar üzerinden belirlenerek sıralanmıştır. Skorların özelliği, test süresince ortaya çıkan ortalama FPS değerini baz almasıdır. Gelişen sistemler zaman içerisinde yerlerini yeni sistemlere bırakırken, son nesil olarak adlandırılan en yeni modeller, teknoloji pazarında büyük yer bulmaktadır. Her birinin farklı performans ve fiyatları olmasıyla beraber aynı zamanda da optimizasyon farklarını da içinde barındırmaktadır. İçinde barındırdığı farklar bakımından yüzlerce hatta binlerce kıyaslama ile karşı karşıya kalan kullanıcılar, soluğu benchmark kıyaslamasında almaktadır. Uygulama açılımı ile birlikte oyun içerisinde görsel ayarlar maksimum düzey olacak şekilde seçilerek değerlendirme işlemine başlanmış olur. Farklı sistemler üzerinde test edilerek ortaya çıkan skorlar, test süresince elde edilen ortalama FPS (Frame Per Second) değerlerinin kendisidir. Bu çalışmamızda, aynı oyun üzerinde farklı teknolojik ürünleri deneyerek "FPS" kıyaslaması yapılmaktadır. Test sonuçları skorlar üzerinden belirlenerek sıralanmıştır. Skorların özelliği, test süresince ortaya çıkan ortalama FPS değerini baz almasıdır.

Anahtar Kelimeler: Oyun performans test, bilgisayar oyunu, FPS testi.

\section{Introduction}

Comparing the results of usage metrics for a computer test is called a computer performance appraisal test. When evaluating performance, computer programs are performed by running along with other processes along with program sequences. Many standardized tests and trials are conducted to improve the relative performance of objects. Computer performance evaluation tests provide methods for comparing the performance of various subsystems in different system architectures.

If a system whose performance will be measured in performance evaluation tests disrupts its functioning, it can make incorrect measurements. For this reason, the functioning should not be disrupted, and the results should be reproducible. Outputs in a measuring system should be interpreted by appropriate statistical methods and made comprehensively consistent [1]. Computer performance assessment tests are programs that investigate the performance of computers and affect the way systems operate. The speed, size, and presentation of the computer system are evaluated and measured by interpretation [2]. Computer performance evaluation tests are used to evaluate the computer piecemeal and piecemeal. Each of its parts affects performance and can be examined separately.

The development of computer games is progressing rapidly with the technology of our age. Thus, computers become widespread and bring their development. As the computing and graphics capabilities of computers increase, the features of computer games also improve, increasing the number of players and companies interested in games. For this reason, many quality games are emerging [3].

Computer games often run on platforms with a variety of processing and display capabilities. A single game title can be published simultaneously on computers, consoles, and handheld devices. Even games released only for computers have significant processing power and video card capabilities [4]. FPS (Frames per second) speed and resolution are the basis for the performance of games. Generally, a higher FPS speed allows for smoother gameplay than a lower FPS speed. FPS speed and resolution may be limited by computer gaming software such as hardware graphics cards or processors [5].

As part of this study, 4 computers were tested in total with the MSI Afterburner test program and the GTA 5 game as a performance evaluation test, and the FPS values of the computers were tested. MSI-developed Afterburner is the most popular video card overclocking tool in overclocking competitions around the world [6]. MSI Afterburner has the best testing conditions in the FPS testing market. It was chosen because it was also ahead of applications such as Fraps and Nvidia Shadowplay. MSI Afterburner is a program that is widely used in the world and provides the control of the most known video cards.

FPS is a unit that helps measure the performance of the display device. On the display screen, the number of full-frame scans that occur every second is shown as the FPS value. The results of the same game and test program on four different computers were examined.

\section{Literature Review}

In the studies carried out, the subject of performance testing for the prototype game of children with attention deficit was explained. It was intended to develop and create a prototype game that could be used to improve children's working memory. CPU usage and average FPS and image memory usage for performance testing were tested in several browsers and determined that the game was good enough to be played on computers [5].

Studies have been conducted on effective sampling-oriented performance tools for GPU (GPU) accelerated supercomputers. This paper describes how to extend performance analysis methods to system-wide gpu accelerated systems [7].

GVirtuS known as service virtualization, graphics using GPU-accelerated for NVIDIA CUDA, Nvidia, so put forth by the computer processing that great impact on performance of a parallel programming gaming anywhere with cloud gaming platform named source research on a thesis on the analysis of system performance measurements. In this study, GPU virtualization was focused on and it was observed that accelerating this unit using NVIDIA CUDA is the key to better performance when using GamingAnywhere [8].

In the research, a new perspective was used to describe the findings of the game according to the camera position and camera usage. It has been observed that frame rate has a much greater effect on the user than resolution in all game perspectives and game movements [9].

A study was conducted on the application of combinatorial tests in Video game tests, and in this study, the application of combinatorial testing, especially involving sequences, was discussed for testing games. Combinatorial testing is an 
experimental design method used to create test scenarios and is primarily used for commercial software testing [10].

An article on automated video game testing using synthetic and human-like intermediaries has been investigated. In this paper, it has been observed that agents can successfully test unexplored levels. The success of human-like and synthetic agents in finding errors was compared and the similarities between human testers were evaluated [11].

A study of user satisfaction measurement in mobile cloud games was examined. A mobile cloud gaming system based on GamingAnywhere is available. Their experience of porting a cloud gaming client to Android, which also applies to other mobile operating systems, has been shared [12].

In a study of visual analysis of game frame rate data, a comprehensive visual analysis system, FPSSeer, is presented to help game designers gain insight into frame rate data. The system has been applied to an online commercial game to monitor its performance and provide feedback to designers and developers [13].

The study examined the network performance analysis of the OnLive system, a commercially available thin client gaming system. Carefully designed experiments measure OnLive game traffic for various game types and analyze bitrates, packet size and time in between for both upstream and downstream game traffic [14].

Studies have been done on frame rate and performance measurement for shooter games. The study presented a unique action classification in FPS games based on interaction requirements that allowed qualitative assessment of the impact of frame rates on player performance. In the analysis of performance results, the ranges tested found that frame rate had a greater impact on performance [15].

A researched article discussed a new online tool for online gamers to share network performance results and generate bulk network performance reports created from data reported by all users [16].

Efficient bitrate reduction techniques are needed to meet the strict network bandwidth requirements of cloud games and support more players. In this study, the concept of the game attention model was introduced and game videos covering a wide range of games were evaluated [17].

\section{Material and Method}

In this study, the MSI Afterburner test program was used to measure the FPS performance of different computers. Assessments of these performances are as important as measuring the performance of computers. Four computers were tested, and their results were obtained.

\subsection{MSI Afterburner}

MSI Afterburner is a program that MSI (Micro-Star International) brand offers to users, where video cards can be controlled. As shown in Table 1, among the most downloaded FPS test programs over the internet, it is the most used video card software according to download rates.

Tablo 1. Download rates of programs

\begin{tabular}{|l|l|}
\hline 1.MSI Afterburner & 150,554 \\
\hline 2.FurMARK & 38,942 \\
\hline 3.PassMARK & 14,597 \\
\hline 4.Cinebench & 2,616 \\
\hline
\end{tabular}

The Program increases user control over computer performance. Thanks to this software, you can easily make settings on the video card. Because it is reliable, it can work on any card and provides full control, allowing you to monitor your hardware in real-time [18].

Although MSI Afterburner is a program that can be used publicly, it can also be used with video cards of all brands. Users can monitor critical hardware resource information such as CPU (Central Processing Unit) usage, GPU (Graphics Processing Unit) usage, and graphics memory usage in real-time. It also provides a recording function, where users can periodically record graphics card benchmarking and all hardware resource usage while simultaneously running the game [19].

The Program provides easy and precise access to overclocking tools (overclocking) and video card settings. Video card voltage adjustments, fan speed control, FPS value display (OSD), average FPS values in the game reporting (Benchmark), video recordings, such as the balance between performance and temperature allows us to find.

The program that targets the graphics card hardware first recognizes the hardware and then provides information about the safest overclocking level. Its main purpose is to prevent the potential damage that overclocking operations will cause to the video card in cases that exceed the user's knowledge. One of the elements that should be considered when overclocking is to keep the video card under surveillance with statistics. These statistics include graphics card temperature and graphics card core speed. It is necessary to create the correct cooling profile to prevent the video card from becoming unusable [20].

\subsubsection{Method}

Before this work is done, the software and software process settings that need to be installed on the computers should be made. The following steps are required for the application.

Step 1: Install MSI Afterburner program

Step 2: Setting the program for the FPS value

Step 3: Making Riva Tuner Statistics Server

Program Settings

Step 4: Opening and testing the GTA 5 Game

Step1: MSI Afterburner program is installed after downloading from the company's official website. As in Figure 1, gives the operating $\mathrm{MHz}$, how much memory is used, and the temperature of the CPU in its first operation. 


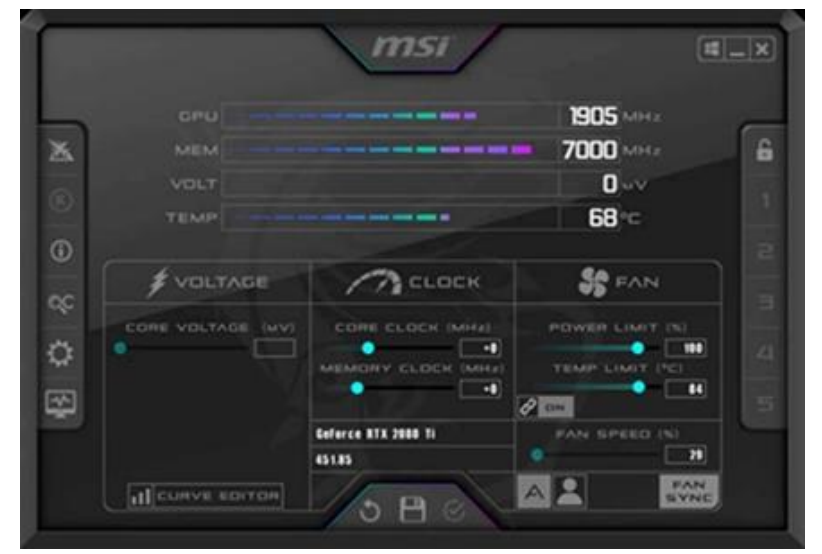

Figure 1. CPU Operating settings screen

Step2: In a standard installation, the FPS value does not appear on the screen. The monitoring section is selected by entering the settings section of the MSI Afterburner program. As in the screenshot in Figure 2, the OSD (information display) part in the fps section should be active. This process will allow us to see the FPS values of our computer on the screen.

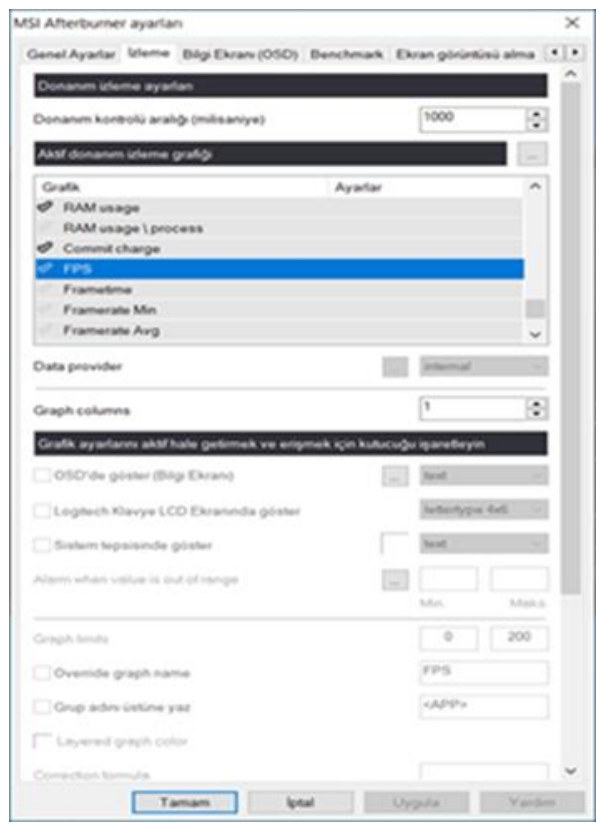

Şekil 2. MSI afterburner ayarlar ekranı

Step3: MSI Afterburner installation can be opened with the Riva Tuner Statistics Server program and the results can be positioned at the desired point as in Figure 3, you can adjust the position of the screen in GTA5.

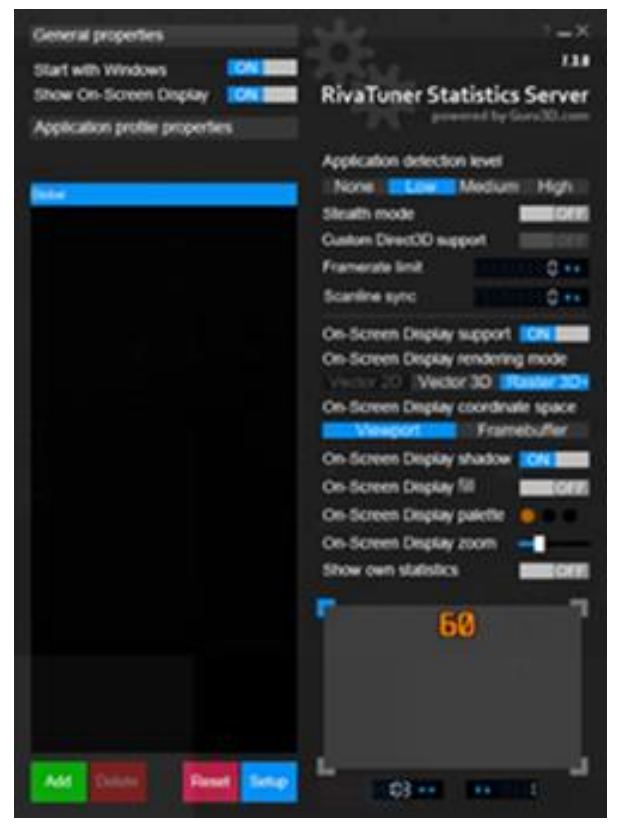

Figure 3. Riva Tuner statistics server display

\section{Application}

The FPS life cycle is also shown in Figure 4. Here, simply put, a video, game, or application sends a frame/image (frame) to the processor for processing, and then after the frame/image is processed in the processor, the graphics processor turns it into a meaningful frame/image (render) and transmits it to the monitor. Our main and important component in this cycle is our graphics processor, which is naturally the biggest factor affecting the FPS value [21]. The graphics card's memory and subcomponents, such as the processor chip, are also important for performance. Another important factor is the computer processor (CPU). The number of cores, speed, and compatibility of the processor with the graphics card are also parameters that affect the FPS value. Another parameter that affects the FPS value is the display (monitor) restrictions. One of the features of screens, the number of refreshes, is a significant limitation to the FPS value. $1 \mathrm{~Hz}$ corresponds to 1 FPS in systems, so screens with a low screen refresh rate cannot be expected to give high FPS scores. As an example, a display with a maximum repeat rate of $60 \mathrm{~Hz}$ cannot display a value of 144 FPS. Screen tearing is also a problem that affects FPS value and game performance. The cause of this problem is the synchronization between the display and the video card. Since the monitor does not immediately render an image, it receives a new image via the GPU during processing and a different image is formed. This problem causes image tears on the screen. Different technology companies have developed software such as Nvidia G-Sync, AMD FreeSync to solve this problem [22].

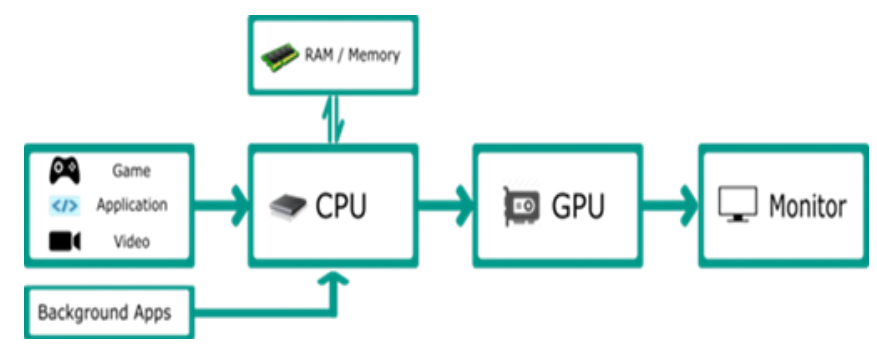

Figure 4. Factors affecting FPS

Scores above 60 FPS in today's video games satisfy visual fluency. 30-60 FPS range is an acceptable level, 30 FPS below the 
visual angle movement is not smooth enough. Graphics settings in games also cause the FPS value to decrease or increase. For example, any video game's graphics settings, such as Resolution, image details, will increase performance by lowering settings, so the FPS value will also increase. In this study, the characteristics of the computers used for testing are given in Table 2.

Table 2. Features of tested computers

\begin{tabular}{|l|l|l|l|l|}
\hline $\begin{array}{l}\text { Display } \\
\text { card }\end{array}$ & $\begin{array}{l}\text { Intel HD } \\
\text { Graphics }\end{array}$ & $\begin{array}{l}\text { NVIDIA } \\
\text { RTX 2060 }\end{array}$ & $\begin{array}{l}\text { NVIDIA } \\
\text { GTX 1060 }\end{array}$ & $\begin{array}{l}\text { RADEON } \\
\text { RX 5600 } \\
\text { XT }\end{array}$ \\
\hline Processor & $\begin{array}{l}\text { Intel I7 } \\
\text { 3632Q 2.20 }\end{array}$ & $\begin{array}{l}\text { Intel I5 } \\
9600 \mathrm{~K} 3.70\end{array}$ & $\begin{array}{l}\text { Intel I5 } \\
8500 ~ 3.00\end{array}$ & $\begin{array}{l}\text { Ryzen 3500x 3.6 5 } \\
\text { 35 }\end{array}$ \\
\hline OS & $\begin{array}{l}\text { Windows } \\
10\end{array}$ & $\begin{array}{l}\text { Windows } \\
10\end{array}$ & $\begin{array}{l}\text { Windows } \\
10\end{array}$ & $\begin{array}{l}\text { Windows } \\
10\end{array}$ \\
\hline Disk & $200 \mathrm{~GB}$ & $250 \mathrm{~GB}$ & $200 \mathrm{~GB}$ & $280 \mathrm{~GB}$ \\
\hline Memory & $6 \mathrm{~GB}$ & $16 \mathrm{~GB}$ & $16 \mathrm{~GB}$ & $16 \mathrm{~GB}$ \\
\hline Score & $\mathbf{0}$ & $\mathbf{1 4 7}$ & $\mathbf{1 3 4}$ & $\mathbf{9 0}$ \\
\hline
\end{tabular}

In the test, the first Intel I7 3632qm $2.2 \mathrm{GHz}$ processor, 200 GB disk space, and 6 GB memory were used. The Second system has Intel I5-9600K $3.7 \mathrm{GHz}$, a disk with a capacity of $250 \mathrm{~GB}$, and 16 GB of ram as memory. The third system used an Intel I5 $85003.00 \mathrm{GHz}$ processor with the same number of cores as the second device. It is set at 16 GB of memory and $200 \mathrm{~GB}$ of disk capacity. In the last system, the processor is a different brand AMD Ryzen 5 3500x $3.6 \mathrm{GHz}$ processor is selected, $16 \mathrm{~GB}$ of RAM with the same value as memory is used and $280 \mathrm{~GB}$ of storage is available in the system. The FPS values screen of the tested computers is shown in Figure 5.

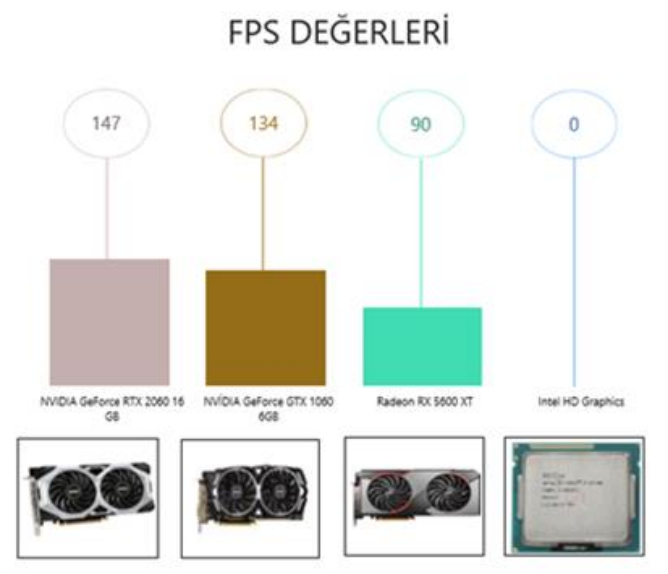

Figure 5. FPS values display

\section{Conclusions and Recommendations}

As a result of the study, data were obtained from the MSI Afterburner FPS test program, which ran on four computers with different hardware characteristics. The Test is based on the GTA $\mathrm{V}$ game. At the same time, the FPS values of the graphics processors tested and the operating speed (Mhz) of the systems, the amount of memory used, and CPU temperature data were collected. As a result of the data collected in the study, the FPS value of different systems was compared on the same game. The Nvidia Geforce RTX 2060 graphics processor achieved the highest FPS value (147) in operation. It belongs to the Nvidia GeForce GTX 1060 graphics processor with a value of 134 FPS, close to the highest value obtained. Although it has approximately the same system features, the Radeon RX 5600 XT graphics card provides an average value of 90 FPS during testing. The FPS value could not be measured on the last computer tested. The Intel HD Graphics graphics processor on the system gave a value of 0 FPS as a test result. The system could not give the required performance, which was insufficient to meet the game requirements, and the said game could not be opened in the system, and the value of 0 FPS was taken as a score. As a result of the tests, Nvidia-branded products from four different graphics processors gave the best FPS score decisively. Nvidia branded graphics processors as a percentage; 39.62\% (RTX 2060), 36.11\% (GTX 1060) by taking the values of a total of $75.73 \%$ gave a value.

The game (GTA V) and software used to better observe the performance of the graphics cards used in the study can be diversified. In this way, the system can be forced, and its actual performance is achieved.

In future studies in a different test environment, healthier results will be achieved with different graphics processors that will be used on a computer with the same system elements and features. Thanks to this test environment, the impact of other system components, such as processor, memory, on the test will be minimized.

Test time is one of the biggest parameters affecting FPS scores. Subsequent studies, such as longer test times or testing identical systems at different times, can allow systems and graphics cards to give more natural FPS scores.

Different programs that show the FPS value, such as the MSI Afterburner test program used in the study, will show the effect of the software on the resulting FPS value when using the same systems and identical tests. In this way, a healthier result can be obtained from graphics cards.

\section{References}

[1] Güler G., 2007, "Bilgisayar performans değerlendirme testleri”, Yüksek lisans tezi, Gazi Üniversitesi, Fen Bilimleri Enstitüsü, Ankara.

[2] Lilja, D. J., "Measuring Computer Performance: A Practitioner's Guide", Cambridge University Press, Cambridge, 10-130 (2000).

[3] Korkusuz, ME ve Karamete, A. (2013). Eğitsel oyun geliştirme modelleri. Necatibey Eğitim Fakültesi Elektronik Fen ve Matematik Eğitimi Dergisi, 7 (2), 78-109.

[4] Claypool, KT ve Claypool, M. (2007). Birinci şahıs nişancı oyunlarında kare hizı ve oyuncu performansı hakkında. Multimedya sistemleri, 13 (1), 3-17.

[5] Bahana, R., Gaol, FL, Wiguna, T., Hendric, SWHL, Soewito, B., Nugroho, E., ... \& Abdurachman, E. (2018, Mart). DEHB olan çocuklar için prototip oyun için performans testi. Gelen Fizik Journal: Shashaa (. Cilt 978, 1 No, s 012.004). IOP Yayıncilık.

[6] Anonim 2021, https://tr.msi.com/Graphics-Card/R9-380GAMING-4G

[7] Chabbi, M., Murthy, K., Fagan, M., \& Mellor-Crummey, J. (2013, November). Effective sampling-driven performance tools for GPU-accelerated supercomputers. In Proceedings of the International Conference on High-Performance Computing, Networking, Storage and Analysis (pp. 1-12).

[8] Sreenibha Reddy, B. (2018). GamingAnywhere'in GPU hızlandırmalı NVIDIA CUDA ile Performans Ölçümleri Analizi. 
[9] Claypool, M., \& Claypool, K. (2009, April). Perspectives, frame rates, and resolutions: it's all in the game. In Proceedings of the 4th International Conference on Foundations of Digital Games (pp. 42-49).

[10] Sagi, BR ve Silvestrini, R. (2017). Video oyun testlerinde kombinatoryal testlerin uygulanması. Kalite Mühendisliği, 29 (4), 745-759.

[11] Ariyurek, S., Betin-Can, A. ve Surer, E. (2019). Sentetik ve insan benzeri ajanlar kullanarak otomatik video oyunu testi. Oyunlarda IEEE İşlemleri.

[12] Huang, CY, Hsu, CH, Chen, DY ve Chen, KT (2014, Mart). Mobil bulut oyunlarında kullanıcı memnuniyetini ölçmek. In Mobile Video Teslimatta Çalıștayı Bildiriler Kitabı (s. 16).

[13] Li, Q., Xu, P., \& Qu, H. (2015, October). FPSseer: Visual analysis of game frame rate data. In 2015 IEEE Conference on Visual Analytics Science and Technology (VAST) (pp. 73-80). IEEE.

[14] Claypool, M., Finkel, D., Grant, A. ve Solano, M. (2012, Kasım). Kazanmak için zayıf mısınız? OnLive ince istemci oyun sisteminin ağ performansı analizi. In 201211 Ağında Yıllık Atölye ve Oyunlar için Sistem Destek (NetGames) (s. 1-6). IEEE.

[15] Claypool, KT ve Claypool, M. (2007). Birinci şahıs nişancı oyunlarında kare hızı ve oyuncu performansı hakkında. Multimedya sistemleri, 13 (1), 3-17.

[16] Mcdonald, N., Leader, D., Chiang, C. K., Khmelevsky, Y., Bartlett, R., \& Needham, A. (2016, June). A new online tool for gamer network performance analysis. In 2016 IEEE International Conference on Cybercrime and Computer Forensic (ICCCF) (pp. 1-6). IEEE.

[17] Ahmadi, H., Tootaghaj, SZ, Hashemi, MR ve Shirmohammadi, S. (2014). Bulut oyunlarında verimli bit hızı tahsisi için bir oyun dikkat modeli. Multimedya Sistemleri, 20 (5), 485-501.

[18] Anonim 2021 , https://www.msi.com/Landing/afterburner/graphics-cards

[19] Sreenibha Reddy, B. (2018). Performance Metrics Analysis of GamingAnywhere with GPU accelerated NVIDIA CUDA.

[20] Anonim 2020, https://donanimarsivi.com/msi-afterburnernasil-kullanilir/

[21] Anonim 2018, https://developingschool.com/a/1/what-isframe-rate-and-factors-affecting-it/

[22] Anonim 2021, https://support.hp.com/trtr/document/c05740177 